DOI: $10.21802 /$ artm.2020.3.15.23.

УДК 616.314-07+616.314.11+616.314-77

\title{
НОВИЙ ПІДХІД ДО ВИБОРУ МЕТОДУ ЛІКУВАННЯ ДЕФЕКТІВ ТВЕРДИХ ТКАНИН ЗУБІВ
}

\author{
О.В. Бульбук
}

Івано-Франківський начіональний медичний університет, кафедра стоматології післядипломної освіти, м. Івано-Франківськ, Україна, ORCID ID: 0000-0001-8985-8254, e-mail: bulbuk85@gmail.com

Резюме. Цілі: вивчити клінічну ефективність запропонованого алгоритму лікування пацієнтів із дефектами твердих тканин зубів.

Методи. Проведене лікування та спостереження за 50 пацієнтами із дефектами твердих тканин зубів різної локалізації, яким проводилося стоматологічне лікування за запропонованим нами алгоритмом. Проводили обстеження самої реставрації за модифікованою методикою USPHS. Тріщини та переломи зубів ми оцінювали та поділяли згідно з класифікацією ААЕ.

Результати. У результаті проведених нами досліджень запропоновано систематизацію дефектів твердих тканин зубів LOV/DD і алгоритм вибору методу лікування дефектів твердих тканин зубів. Для перевірки ефективності запропонованого алгоритму було проведене лікування, згідно з запропонованим нами алгоритмом, та спостереження за 50 пацієнтами із дефектами твердих тканин зубів різної локалізації. При оцінці ефективності запропонованого алгоритму, після проведеного нами лікування пацієнтів, відсоток успішного лікування впродовж 18 місяців загалом становив $(96,0 \pm 2,8) \%$ за критеріями USPHS. Проаналізувавши результати дослідження ускладнень, нами відмічено, що в цих пацієнтів не спостерігалися випадки різних типів переломів зубів чи втрати зубів.

Висновки. При плануванні ортопедичного лікування пацієнтів із дефектами твердих тканин зубів рекомендується використовувати розроблений алгоритм вибору методу лікування дефектів твердих тканин зубів, що базується на запропонованій нами систематизації LOV/DD. При дефектах 3/3, 3/4, 4/1, 4/2 доцільно використовувати непряму реставрацію, при дефектах 4/3, 4/4 - штучні коронки, а у всіх інших випадках лікування проводити методом прямої реставрації.

Ключові слова: систематизація, дефект твердих тканин зуба, діагностика, реставрація, алгоритм вибору лікування.

Вступ. Для ухвалення правильного рішення щодо вибору методу лікування дефектів твердих тканин зубів лікар повинен ураховувати декілька факторів, як-от: величину та місце розташування порожнин, причини, які призвели до втрати твердих тканин зубів, зміни в пародонті. Адже дефекти коронкових частин зубів призводять до порушення функцій жування, розвитку вторинних деформацій, захворювання жувальних м'язів та скроневонижньощелепного суглоба [1-3].

На думку С.В. Радлінського [4], розподіл за спеціальностями в стоматології, що практикується 3 ранніх періодів навчання на стоматологічних факультетах, сприяє формуванню в лікарів одностороннього погляду на стоматологічне здоров'я пацієнта. Розподіл за спеціальностями деколи заважає формуванню загальноклінічного та загальностоматологічного мислення в лікарів. Особливо великий дисонанс виникає при виборі методу лікування дефектів твердих тканин зубів. Вибір методу схожий на протистояння терапевтів-стоматологів та стоматологівортопедів, оскільки з вдосконаленням реставраційних матеріалів розширилися показання до прямих реставрацій, що збільшило кількість ускладнень.

Обгрунтування дослідження. Лікування дефектів твердих тканин зубів у більшості випадків пов'язане $з$ вибором методик відновлення анатоміч- ної форми зуба та матеріалів, які будуть використовуватись. Допомогу при виборі методу відновлення зруйнованої коронки зуба та постановці діагнозу може надати запропонований В.Ю. Мілікевічем (1984) індекс руйнування оклюзійної поверхні зуба (IPOПЗ) для I та II класу за Блеком [2]. Світова стоматологічна спільнота опирається на інші показники: «intercuspal distance» (міжгорбкова відстань), SI/STA $[5,6]$.

Найпершим важливим завданням лікарівстоматологів при лікуванні дефектів твердих тканин зубів $\epsilon$ адекватний вибір методу лікування, який залежить від багатьох факторів: величини дефекту та етіології, естетичних, оклюзійних, ендодонтичних та пародонтальних аспектів; кількості уражених зубів. Вибір між прямим та непрямим методами реставрації ускладнюється тим, що залежить не від об'єктивних чинників, а від власних знань, звичок, переваги та «стереотипів» лікаря-стоматолога щодо лікування таких патологій; згоди пацієнта, його фінансових можливостей та інших чинників, які не мають нічого спільного з методами доказової медицини [7-10].

Таким чином, проблема вибору методу лікування дефектів твердих тканин зубів потребує досконалого вивчення та розробки нових підходів згідно 3 принципами доказової медицини. 
Мета дослідження. Вивчити клінічну ефективність запропонованого алгоритму лікування пацієнтів із дефектами твердих тканин зубів.

Матеріали і методи. Для досягнення поставленої мети і для перевірки ефективності запропонованого алгоритму було проведено лікування та спостереження за 50 пацієнтами із дефектами твердих тканин зубів різної локалізації, яким проводилося стоматологічне лікування за запропонованим нами алгоритмом [10]. При обстеженні пацієнтів спочатку звертали увагу на скарги, що пов'язані з раніше виготовленими реставраціями. Проводили опитування щодо виду лікування та терміну користування реставрацією. Проводили обстеження самої реставрації за модифікованою методикою USPHS (United States Public Health Service) (Ryge G.) [11], звертали увагу на матеріал, із якого вона виготовлена, спосіб виготовлення. Для визначення якості реставрації було оцінено анатомічну форму, крайову адаптацію, шорсткість поверхні, крайове забарвлення, відповідність кольору та наявність дискомфорту чи чутливості. Визначення оклюзійних контактів проводили за до- помогою оклюзійного паперу. Із метою отримання додаткових даних про глибину руйнування проводилися рентгенологічні обстеження та діагностика вторинного карієсу за допомогою апарату DIAGNOdent. Тріщини та переломи зубів ми оцінювали та поділяли згідно з класифікацією ААЕ (Американської асоціації ендодонтів) [12].

Результати дослідження та їх обговорення. У результаті проведених нами досліджень запропоновано систематизацію дефектів твердих тканин зубів LOV/DD (табл. 1) і алгоритм вибору методу лікування дефектів твердих тканин зубів, що базується на систематизації LOV/DD та може слугувати критерієм вибору при лікуванні цієї патології [10]. Наше удосконалення діагностичного процесу дефектів твердих тканин зуба сприяє вирішенню проблеми систематизації і вибору тактики стоматологічного лікування пацієнтів із цією патологією.

У нашій систематизаціїі є два поділи, що відображені в табл. 1, які утворять систематизацію $\mathrm{LOV} / \mathrm{DD}$.

Систематизація LOV/DD

Таблиця 1

\begin{tabular}{|c|c|c|}
\hline & $\begin{array}{c}\text { Місие розмімення дефектів (Location), оклюзійне навантаження } \\
\text { (Occlusion), об'єм дефектів (Volume) } \\
\text { LOV }\end{array}$ & $\begin{array}{c}\text { Глибина ураження (depth of destruc- } \\
\text { tion) } \\
\text { DD }\end{array}$ \\
\hline $\mathbf{0}$ & & $\begin{array}{l}\text { порожнина не визначається (деміне- } \\
\text { ралізація, дисколорит, зміни анатомі- } \\
\text { чної форми зуба); }\end{array}$ \\
\hline 1 & $\begin{array}{l}\text { - } \quad \text { дефекти в ділянці природних ямок та фісур; } \\
\text { - } \quad \text { одно- та двосторонні дефекти на різцях та іклах розміром до 1/2 } \\
\text { довжини різального краю зі збереженою вестибулярною поверхнею і } \\
\text { оптимальною кількістю дентину на ній; } \\
\text { • } \quad \text { дефекти пришийкової ділянки всіх груп зубів та вільним операти- } \\
\text { вним доступом до них. }\end{array}$ & $\begin{array}{l}\text { ураження емалі та початкове уражен- } \\
\text { ня дентину, глибина порожнини в } \\
\text { межах зовнішньої } 1 / 3 \text { дентину; }\end{array}$ \\
\hline 2 & $\begin{array}{l}\text { - } \text { дефекти на молярах і премолярах по типу O, зі збереженою стін- } \\
\text { кою не менше } 20 \% \text { діаметру коронки зуба; } \\
\text { - } \quad \text { дефекти на молярах і премолярах типу OM (OD) та MOD без } \\
\text { ураження опорних горбків та товщиною збережених стінок не менше } \\
\text { 20\% від діаметру коронки зуба; } \\
\text { • } \quad \text { дефекти на різцях та іклах із ураженням вестибулярної поверхні } \\
\text { до одної третини. }\end{array}$ & $\begin{array}{l}\text { помірне ураження дентину, глибина } \\
\text { порожнини в межах середньої трети- } \\
\text { ни дентину; }\end{array}$ \\
\hline 3 & 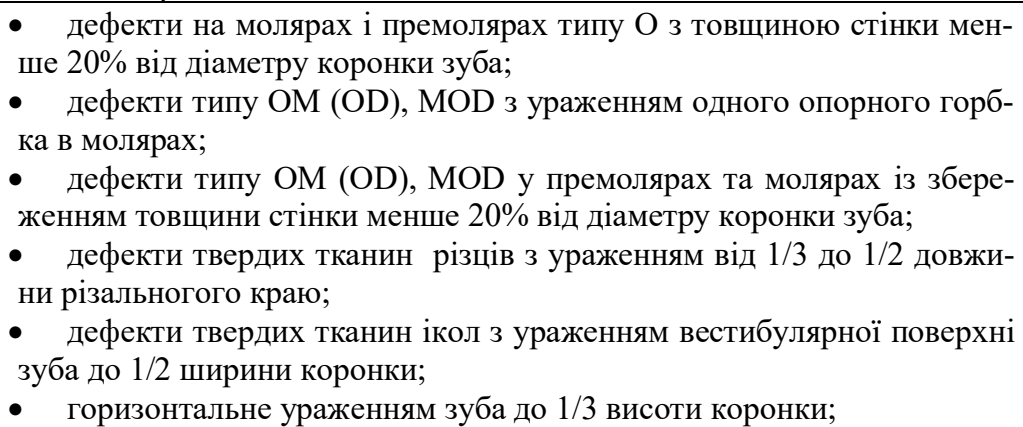 & $\begin{array}{l}\text { глибоке ураження дентину, глибина } \\
\text { порожнини в межах навколопульпар- } \\
\text { ного дентину. }\end{array}$ \\
\hline 4 & 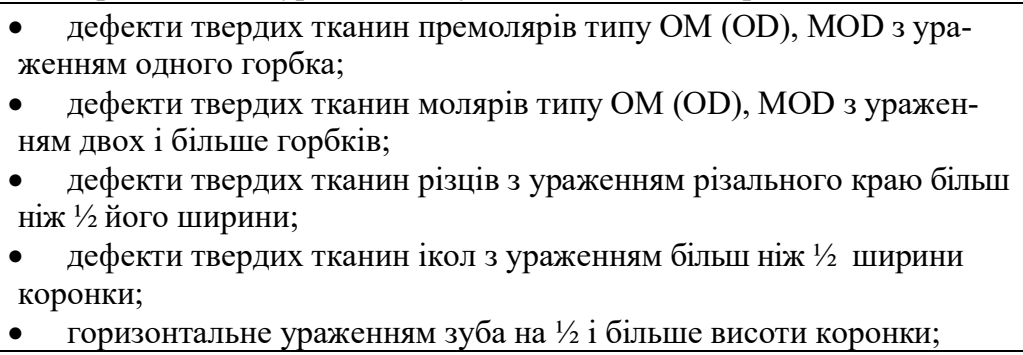 & зуби після ендодонтичного лікування; \\
\hline
\end{tabular}


Відповідно до проведених нами досліджень ми запропонували алгоритм вибору методу лікування дефектів твердих тканин зубів, що базується на систематизації LOV/DD (табл. 2).

За результатами наших досліджень, зокрема механіко-математичного моделювання [10], ми вважаємо, що дефекти 4/3, 4/4 доцільно лікувати за допомогою штучних естетичних коронок.

Дефекти 3/3, 3/4, на нашу думку, потребують лікування за допомогою непрямої реставрації.

Тактика ведення таких пацієнтів із дефектами 4/0 залежить від етіології та глибини зміни кольору зуба. Сьогодні такі зуби лікуються шляхом зовнішнього або внутрішнього відбілювання або менш консервативними методами: непрямою реставрацією і штучними коронками.

Лікування всіх інших дефектів, згідно з систематизацією LOV/DD, на нашу думку, можна проводити за допомогою непрямої реставрації.

Загалом, на нашу думку, пропонована систематизація LOV/DD відкриває перспективи знаходження консенсусу щодо диференційованих діагностично-лікувальних підходів при різних клінічних варіантах дефектів твердих тканин зубів.

Алгоритм вибору методу лікування дефектів твердих тканин зубів

Таблиця 2

\begin{tabular}{|c|c|}
\hline Вид лікування & Систематизація LOV/DD \\
\hline Пряма реставрація & $\begin{array}{l}\text { Дефекти 1/0, 1/1, 1/2, 1/3, 1/4; } \\
\text { Дефекти 2/0, 2/1, 2/2, 2/3, 2/4; } \\
\text { Дефекти 3/0, 3/1, 3/2 }\end{array}$ \\
\hline Непряма реставрація & $\begin{array}{l}\text { Дефекти 3/3, 3/4 } \\
\text { Дефекти 4/1, 4/2 } \\
\text { Дефекти 4/0* }\end{array}$ \\
\hline Штучні естетичні коронки & Дефекти 4/3, 4/4** \\
\hline
\end{tabular}

\section{Примімки:}

*Тактика ведення таких хворих із дефектами 4/0 залежить від етіології та глибини зміни кольору зуба. Сьогодні такі зуби лікуються шляхом зовнішнього або внутрішнього відбілювання або менш консервативними методами: непрямою реставрацією і штучними коронками.

**Тактика ведення таких хворих із дефектами 4/4: для відновлення кукси зуба рекомендуємо встановлення скловолоконних штифтів.

Для перевірки ефективності запропонованого алгоритму було проведено лікування та спостереження за 50 пацієнтами із дефектами твердих тканин зубів різної локалізації, яким проводилося стоматологічне лікування за запропонованим нами алгоритмом.

Пацієнту після видалення уражених тканин проводили виміри за допомогою мікрометра у фронтальній групі зубів ширини збереженої вестибулярної поверхні, а в боковій групі зубів - товщини збереженої стінки. Розраховували співвідношення товщини стінки до діаметру зуба та враховували втрату опорних горбків у боковій групі зубів, визначали глибину ураження. Базуючись на цих вимірах, ми провели діагностування за допомогою систематизації LOV/DD (див. табл. 1) і вибрали метод лікування, згідно з алгоритмом (табл. 2). Лікування методом прямої реставрації проведено 30 пацієнтам із використанням композиту світлової полімеризації GC Gradia Direct ANTERIOR та GC Gradia Direct Posterior. Проведено лікування методом непрямої реставрації 20 пацієнтам із використанням вкладок із прес-кераміки IPS E.max Press (Ivoclar Vivadent, Лixтенштейн), які були зафіксовані композитним цементом Panavia SA+ (Kuraray Noritake, Японія).

Клінічну оцінку реставрацій проводили за модифікованою методикою USPHS одразу після встановлення реставрацій та через $6,12,18$ місяців в усіх пацієнтів 3-ї групи дослідження. Проводилась оцінка таких параметрів: анатомічна форма (AF), крайова адаптація (MA), шорсткість поверхні (SR), крайове забарвлення (MD), відповідність кольору (CM), дискомфорт/ чутливість (OF), наявність вторинного карієсу (SC).

Безпосередньо після встановлення реставрації всі 50 пацієнтів отримали оцінки A (Alpha) у 100 \% випадків за критеріями USPHS.

Наступним етапом була оцінка виготовлених нами реставрацій через 6 місяців. Підчас оцінки пацієнтів, яким проведено лікування, виявили 1 випадок $(2,0 \pm 2,0) \%$ порушення крайового забарвлення (MD) 3 оцінкою В (Bravo). За всіма іншими критеріями USPHS ми не виявили жодних змін.

Через 12 місяців ми провели оцінку виготовлених нами реставрацій. Згідно з критерієм наявності вторинного карієсу (SC) виявили, що в $1(2,0 \pm 2,0) \%$ випадку були ознаки вторинного карієсу, оцінка C (Charlie). Цю реставрацію потрібно було переробляти. Решта реставрацій відповідали оцінкам А і В.

Клінічні спостереження, згідно 3 модифікованими критеріями USPHS, через 18 місяців показали такі результати: у $1(2,0 \pm 2,0) \%$ клінічному випадку ми спостерігали порушення крайової адаптації (МА), що відповідає оцінці С. Решта реставрацій відповідали оцінкам А і В.

Таким чином, при оцінці ефективності запропонованого алгоритму, після проведеного нами лікування пацієнтів, відсоток успішного лікування впродовж 18 місяців загалом становив $(96,0 \pm 2,8) \%$ за критеріями USPHS. Лише в 2 клінічних випадках 
$(4,0 \pm 2,8)$ \% ці реставрації потребували заміни (з оцінкою Charlie (C)). Проаналізувавши результати дослідження ускладнень, нами відмічено, що в цих пацієнтів не спостерігалися випадки різних типів переломів зубів чи втрати зубів.

Проведені нами дослідження доповнюють наші наукові роботи та роботи інших дослідників, які свідчать про те, що алгоритм вибору методу лікування дефектів твердих тканин зубів, що базується на систематизації LOV/DD, може слугувати критерієм вибору при лікуванні цієї патології $[10,13,14]$.

Проведені нами дослідження дозволяють стверджувати, що при правильному виборі методу лікування дефектів твердих тканин зубів кількість клінічних ситуацій із несприятливим прогнозом для таких зубів (аж до їхньої втрати) зменшується. Отримані результати схожі із даними інших досліджень [14-18].

Висновки. При плануванні ортопедичного лікування пацієнтів із дефектами твердих тканин зубів рекомендується використовувати розроблений алгоритм вибору методу лікування дефектів твердих тканин зубів, що базується на запропонованій нами систематизації LOV/DD. При дефектах 3/3, 3/4, 4/1, 4/2 доцільно використовувати непряму реставрацію, при дефектах 4/3, 4/4 - штучні коронки, а у всіх інших випадках лікування проводити методом прямої реставрації.

Клініко-статистичне дослідження довело ефективність і переваги запропонованого алгоритму вибору методу лікування дефектів твердих тканин зубів.

Вивчення дефектів твердих тканин зубів і систематизація отриманих результатів дозволить оптимізувати діагностичний процес при лікуванні даної патології.

\section{References:}

1. Mrikaeva MR, Skryl' AV, Pecherskih EA. Analiz oshibok i oslozhnenij pri vosstanovlenii defektov koronkovoj chasti zuba shtiftovymi konstrukcijami zubnyh protezov. Medicinskij vestnik Severnogo Kavkaza. 2012;(4):89-90.

2. Bulbuk OI, Rozhko MM. Obstezhennia khvorykh v klinitsi ortopedychnoi stomatolohii: navchalnyi posibnyk. Ivano-Frankivsk: Lileia-NV; 2009. 148 p. [In Ukrainian]

3. Bulbuk OV, Rozhko MM, Bulbuk OI. Suchasni pidkhody do vyboru metodu stomatolohichnoho likuvannia defektiv tverdykh tkanyn zubiv (ohliad literatury). Art of medicine. 2018; 2(6): 130-136. [In Ukrainian]

4. Radlinskij SV. Vidy prjamoj restavracii zubov. DentArt. 2004;1:33-40.

5. Smithson J, Newsome P, Reaney D, Owen S. Direct or indirect restorations? Int Dent. 2011;1(1):70-80.

6. Zarow MD, Arcangelo C, Paolone G, Paniz G, Felipe L. EndoProsthodontics - Guidelines for the clinical practice. Chicago: Quintessence Int; 2016.

7. Christensen GJ. Restoration or crown? J Am Dent Assoc. 1997 Jun;128(6):771-2.

8. Dietschi D, Devigus A. Prefabricated composite veneers: historical perspectives, indications and clinical application. Eur J Esthet Dent. 2011 Summer;6(2):178-87.

9. Mount GJ, Ngo H. Minimal intervention: a new concept for operative dentistry. Quintessence Int 2000;31:527-533.

10. Bulbuk OV, Rozhko MM, Bulbuk OI. Suchasni pidkhody do stomatolohichnoho likuvannia defektiv tverdykh tkanyn zubiv: monohrafiia. Ivano-Frankivsk: IFNMU; 2020. 145 p. [In Ukrainian]

11. Bayne, Stephen C.; Schmalz, Gottfried; (2005). "Reprinting the classic article on USPHS evaluation methods for measuring the clinical research performance of restorative materials." Clinical Oral Investigations 9(4): 209-214.

12. Endodontics: Colleagues for Excellence [Internet]. Chicago: AAE; summer 2008. Available from: https:/www.aae.org/specialty/wpcontent/uploads /sites/2/2017/07/ecfesum08.pdf

13. Mount GJ, Hume WR. A new cavity classification. Aust Dent J. 1998 Jun;43(3):153-9.

14. Gargari M, Ceruso FM, Pujia A, Prete V. Restoration of anterior teeth using an indirect composite technique. Case report. Oral Implantol (Rome). 2014 May 19;6(4):99-102. Collection 2013 Apr.

15. Christensen GJ. Considering tooth-colored inlays and onlays versus crowns. J Am Dent Assoc. 2008;(139):617-620.

16. Christensen GJ. Has tooth structure been replaced. See comment in PubMed Commons below J Am Dent Assoc. 2002;(133):103-105.

17. Christensen GJ. Intracoronal and extracoronal tooth restorations. See comment in PubMed Commons below J Am Dent Assoc. 1999;(130):557-560.

18. Geurtsen W, Schwarze T, Günay H. Diagnosis, therapy, and prevention of the cracked tooth syndrome. See comment in PubMed Commons below Quintessence Int. 2003;(34):409-417.

\section{УДК 616.314-07+ 616.314.11+ 616.314-77 НОВЫЙ ПОДХОД К ВЫБОРУ МЕТОДА ЛЕЧЕНИЯ ДЕФЕКТОВ ТВЕРДЫХ ТКАНЕЙ ЗУБОВ}

О.В. Бульбук

Ивано-Франковский национальный медицинский университет, кафедра стоматологии ПО,

2. Ивано-Франковск, Украина,

ORCID ID: 0000-0001-8985-8254,

e-mail:bulbuk85@gmail.com

Резюме. Цели: изучить клиническую эффективность предложенного алгоритма лечения пациентов с дефектами твердых тканей зубов.

Методы. Проведено лечение и наблюдение за 50 пациентами с дефектами твердых тканей зубов различной локализации, которым проводилось стоматологическое лечение по предложенному нами алгоритму. Проводили обследование самой реставрации по модифицированной методике USPHS. Трещины и переломы зубов мы оценивали и разделяли, согласно классификации АAE. 
Результаты. В результате проведенных нами исследований предложено систематизацию дефектов твердых тканей зубов LOV/DD и алгоритм выбора метода лечения дефектов твердых тканей зубов. Для проверки эффективности предложенного алгоритма было проведено лечение, согласно предложенных нами методов, и наблюдения за 50 пациентами с дефектами твердых тканей зубов различной локализации. При оценке эффективности предложенного алгоритма, после проведенного нами лечения пациентов, процент успешного лечения в течение 18 месяцев в целом составил $(96,0 \pm 2,8) \%$ по критериям USPHS. Проанализировав результаты исследования осложнений, нами отмечено, что в этих пациентов не наблюдались случаи различных типов переломов зубов или потери зубов.

Выводы. При планировании ортопедического лечения пациентов с дефектами твердых тканей зубов рекомендуется использовать разработанный алгоритм выбора метода лечения дефектов твердых тканей зубов, основанный на предложенной нами классификации LOV/DD. При дефектах 3/3, 3/4, 4/1, 4/2 целесообразно использовать непрямую реставрацию, при дефектах 4/3, 4/4 - искусственные коронки, а во всех остальных случаях лечение проводить методом прямой реставрации.

Ключевые слова: систематизация, дефект твердых тканей зуба, диагностика, реставрация, алгоритм выбора лечения.

\section{UDC 616.314-07+ 616.314.11+ 616.314-77 \\ A NEW APPROACH TO THE CHOICE OF TREATMENT OF DEFECTS OF HARD TISSUES OF TEETH}

\section{O.V. Bulbuk}

\author{
Ivano-Frankivsk National Medical University, \\ Department of Dentistry, \\ Ivano-Frankivsk, Ukraine, \\ ORCID ID: 0000-0001-8985-8254, \\ e-mail: bulbuk85@gmail.com
}

Abstract. Objectives: to study the clinical effectiveness of the proposed algorithm for the treatment of patients with defects in the hard tissues of the teeth.

Methods. To achieve this goal and test the effectiveness of the proposed algorithm, treatment and observation of 50 patients with defects of hard tissues of the teeth of different localization, who received dental treatment according to our proposed algorithm. During the examination of the patients, they first paid attention on the complaints related to previously made restorations. Surveys were conducted on the type of treatment and duration of the restoration. The restoration itself was carried out according to the modified USPHS method, attention was paid to the material from which it is made, the method of manufacture. Anatomical shape, marginal adaptation, surface roughness, marginal color, color matching, and discomfort or sensitivity were assessed to determine the quality of the restoration. We evaluated and divided cracks and fractures of teeth according to the AAE classification.

Results. As a result of our research, we proposed the systematization of dental hard tissue defects LOV/DD and the algorithm for choosing the method of treatment of dental hard tissue defects, based on the systematization LOV/DD and can serve as a selection criterion in the treatment of this pathology. To test the effectiveness of the proposed algorithm, treatment and observation of 50 patients with defects of the hard tissues of the teeth of different localization, who underwent dental treatment according to our proposed algorithm. When evaluating the effectiveness of the proposed algorithm, after our treatment of patients, the percentage of successful treatment for 18 months was generally $(96.0$ $\pm 2.8) \%$ according to USPHS criteria. Only in 2 clinical cases $(4.0 \pm 2.8) \%$ these restorations needed to be replaced (with a Charlie score $(\mathrm{C})$ ). After analyzing the results of the study of complications, we noted that these patients did not have cases of different types of fractures or tooth loss.

Our researches allow us to state that with the right choice of treatment for dental defects, the number of clinical situations with an unfavorable prognosis for such teeth (up to their loss) decreases. Thus, we can conclude that the proposed systematization fills the obvious gap in academic ideas about hard tissue defects, opens the prospect of reaching a consensus on differentiated diagnostic and therapeutic approaches in dental treatment of patients with this pathology and lays a methodological «bridge of continuity» between therapeutic and orthopedic methods of treatment in the field of treatment of defects of hard tissues of teeth.

Conclusions. It is recommended to use the developed algorithm for selecting the method of treatment of defects of hard tissues of teeth when planning the orthopedic treatment of patients with defects of hard tissues of teeth, based on our proposed systematization LOV/DD. At defects 3/3, 3/4, 4/1, 4/2 it is expedient to use indirect restoration, at defects $4 / 3,4 / 4$ - artificial crowns, and in all other cases to carry out treatment by a method of direct restoration.

According to the indicators of clinical and statistical research, the efficiency and advantages of the proposed algorithm for choosing the method of treatment of defects of dental hard tissues, based on our proposed systematization of LOV / DD, are proved.

Keywords: systematization, defect of hard tissues of a tooth, diagnostics, restoration, algorithm of choice of treatment. 